\title{
The Laccate Ganoderma of the Southeastern United States: A Cosmopolitan and Important Genus of Wood Decay Fungi ${ }^{1}$
}

\author{
Andrew L. Loyd, Jason A. Smith, Brantlee S. Richter, Robert A. Blanchette, and Matthew E. \\ Smith ${ }^{2}$
}

\section{Summary}

Ganoderma Karst. is a large and diverse genus of wood decay fungi that can rot the roots and/or lower trunk of many tree species. There are several laccate (varnished or polished) Ganoderma species that are found in the southeastern United States. These species can be recognized by their shiny, reddish-brown, and shelf-like fruiting bodies. These fruiting bodies have a pale pore surface on the bottom that darkens with age or handling and can be stipitate (stem present) or sessile (stem absent). Laccate Ganoderma species fruit year-round in most parts of the southeastern United States, but fruiting may be restricted to warm months in northern areas. When Ganoderma fruiting bodies are observed, it is an indication that wood decay is active, whether on fallen logs, buried roots, or the trunks of living or dead trees.

\section{Introduction}

Ganoderma species are white rot fungi, which means they can break down both cellulose and lignin, the structural components of wood (Sinclair and Lyon 2005). Ganoderma species are generally associated with the decay of roots and/or the lower trunk and root flare, which can lead to hazardous tree conditions and tree failures, resulting in serious damage to property and life.

Fruiting bodies of Ganoderma are often found in association with declining trees, especially in urban landscapes. However, they can also be found at the base of affected living trees where there are localized pockets of decay within the tree, on dead trees, or associated with buried infected wood or roots of previously removed trees. The presence of Ganoderma fruiting bodies on living trees does not always indicate imminent tree failure or death, and some Ganoderma species are more aggressive pathogens than others. For example, G. zonatum Murrill has been documented as a serious pathogen of palm trees and can contribute to tree mortality and failure by windthrow (Elliott and Broschat 2001) (Figure 1A). Other species, such as G. sessile Murrill and G. curtisii (Berk.) Murrill, seem to be opportunistic pathogens and typically only cause serious decay in old or stressed trees (Sinclair and Lyon 2005). Some tree species, such as Quercus virginiana (southern live oak), can resist decay because they produce dense wood with antimicrobial chemicals and they compartmentalize infections. In contrast, species such as Quercus hemisphaerica ("laurel" or Darlington oak) are less efficient at combating fungal infections and are therefore more susceptible to decay.

1. This document is PP333, one of a series of the Plant Pathology Department, UF/IFAS Extension. Original publication date January 2017. Visit the EDIS website at http://edis.ifas.ufl.edu.

2. Andrew L. Loyd, graduate student, School of Forest Resources and Conservation; Jason A. Smith, associate professor, School of Forest Resources and Conservation; Brantlee S. Richter, lecturer, Plant Pathology Department; Robert A. Blanchette, professor, Department of Plant Pathology, University of Minnesota; and Matthew E. Smith, assistant professor, Plant Pathology Department; UF/IFAS Extension, Gainesville, FL 32611.

The Institute of Food and Agricultural Sciences (IFAS) is an Equal Opportunity Institution authorized to provide research, educational information and other services

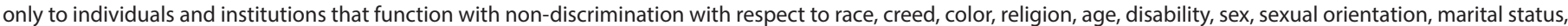

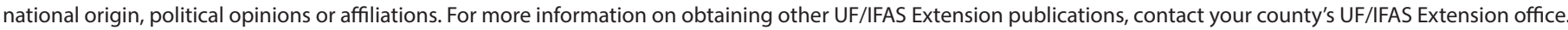
U.S. Department of Agriculture, UF/IFAS Extension Service, University of Florida, IFAS, Florida A \& M University Cooperative Extension Program, and Boards of County Commissioners Cooperating. Nick T. Place, dean for UF/IFAS Extension. 
Knowledge of which Ganoderma species is present and what tree species is infected can assist with tree structure evaluations and risk assessments of hazardous trees.

\section{Taxonomy}

The taxonomy (classification) of North American Ganoderma species is quite confusing and has been in a state of flux for the past 20 years. However, with the advancement of molecular genetic investigations, the species complex is being elucidated (Cao et al. 2012; Moncalvo et al. 1995; Zhou et al. 2015). In the past century, many authors that have reported findings of Ganoderma in the United States have used the name 'G. lucidum' for any laccate Ganoderma species growing on hardwood trees (Adaskaveg and Gilbertson 1988, 1989; Gilbertson and Ryvarden 1986; Hapuarachchi et al. 2015). It is now recognized that G. lucidum sensu stricto (Curtis) Karst only occurs endemically in Europe and possibly northeastern China (Cao et al. 2012; Hennicke et al. 2016; Moncalvo et al. 1995). Similarly, many of the wild-collected and commercially available cultivated species have been given the general label of 'G. lucidum' in Asia, where laccate Ganoderma species have been used for medicinal purposes for centuries (Hennicke et al. 2016; Wang et al. 2012). This group of fungi are commonly referred to as "reishi" or "Ling-zhi" (Hennicke et al. 2016). It is now recognized that cultivated "reishi or "Ling-zhi" in Asia actually represents several species, such as G. lingzhi Sheng H. Wu, Y. Cao \& Y.C. Dai, G. sichuanense J.D. Zhao \& X.Q. Zhang, and G. multipileum Ding Hou (Cao et al. 2012).

\section{Laccate Ganoderma Species of the Southeastern United States}

There are approximately ten laccate Ganoderma species that have been reported in the southeastern United States (Alabama, Florida, Georgia, Mississippi, North Carolina, South Carolina, and Tennessee). These are G. curtisii, G. martinicense Welti \& Court., G. meredithiae Adask. \& Gilb., G. ravenelii Stayaert, G. sessile, G. tsugae Murrill, G. tuberculosum Murrill, G. weberianum (Bres. \& Henn.) Steyaert, G. zonatum, and Tomophagus colossus (Fr.) Murrill (formerly known as G. colossum (Fr.) Baker). The most commonly observed species in the southeastern United States are G. curtisii and G. sessile, but in Florida G. zonatum is also commonly found, specifically on palm trees (Figure 1).

The morphology of basidiocarps (conks) of the laccate Ganoderma species can be highly variable, which presents challenges for species level identification. For example, species such as G. curtisii and G. meredithiae are practically identical in the field. However, the former is typically found in association with hardwood trees (especially oaks), while the latter is associated with pines. Some species are generalists and can be found in association with a diverse range of host trees, and other species are specialists. For example, $G$. sessile is a generalist that can be commonly found on many species, such as oaks, maples, redbuds, and other deciduous trees, whereas Ganoderma zonatum is a specialist that can only be found on palms.

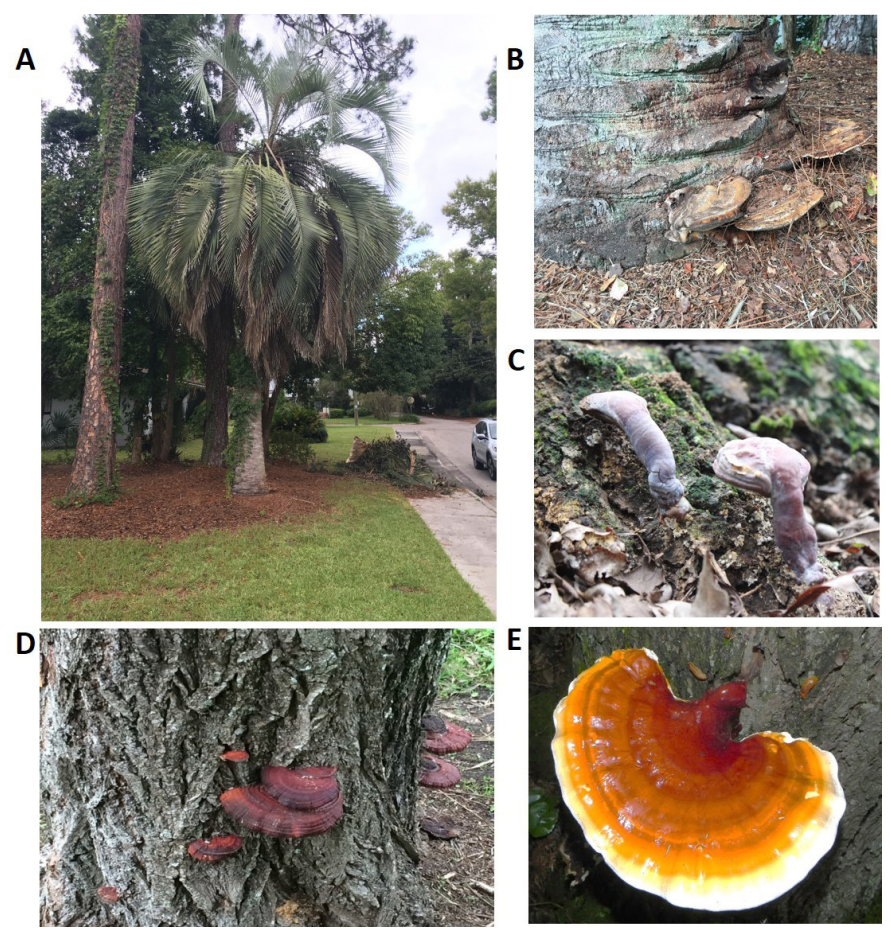

Figure 1. Common laccate Ganoderma species of the southeastern United States. A) Canopy collapse symptom of Butia odorata (Jelly palm) infected with Ganoderma zonatum; B) Ganoderma zonatum fruiting on a trunk of B. odorata; C) Ganoderma curtisii fruiting bodies on a root flare of a Quercus sp. (oak); D) Ganoderma sessile fruiting bodies on a trunk of a Salix sp. (willow); E) Ganoderma tsugae fruiting on Tsuga canadensis (hemlock) trunk.

Credits: A) Andrew Loyd, UF/IFAS; B) Andrew Loyd, UF/IFAS; C) Andrew Loyd, UF/IFAS; D) Matt Losey, Bartlett Tree Experts; E) Robert Blanchette, University of Minnesota, Department of Plant Pathology

Generally, all laccate Ganoderma species have woody to spongy fruiting bodies that grow on the lower portions of trees (i.e. lower trunk, root flare, roots, etc.). The characteristics that are most helpful for species identification are the color of the fruiting body, whether it has stipitate or sessile anatomy (presence or absence of a stalk), context tissue characters (tissues between cap crust and tubes and throughout the stem, Figure 3A), and host tree species. Fruiting bodies range in color from yellow to brown to reddish-brown and are mostly "shiny" on non-spore producing surfaces. Stipes (stalks) can be present or absent (sessile) and when present can range from short, stocky 
stalks that are referred to as pseudostipes to lengths that are equal to or greater than the diameter of the cap (Figure 2). The context tissue ranges from white or cream to dark brown in color and corky to felty in texture. Black, often shiny, resinous deposits throughout the length of the stipe and/or concentric zones in the context tissue are features that are important characteristics for some species (Figure $3)$.
A

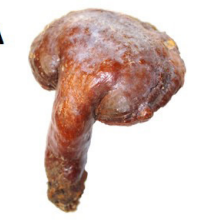

C

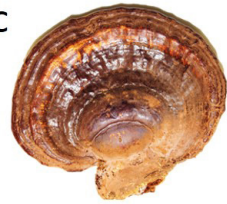

E

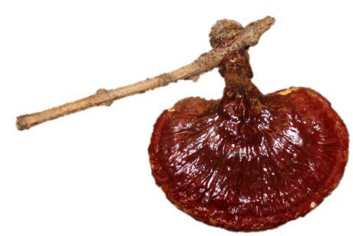

B

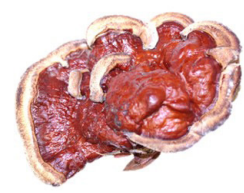

D

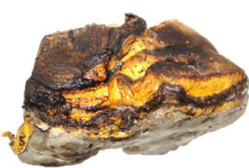

$\mathbf{F}$

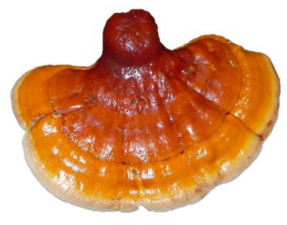

Figure 2. Range of different macromorphological characters of laccate Ganoderma spp. A) Reddish-brown with subtle purple hues of a stipitate form of a typical G. curtisii; B) Highly varnished, red sessile fruiting body typical of $G$. sessile; C) Reddish-brown, sessile form of $G$. zonatum with conspicuous concentric zones typical of this species; D) Yellow, spongy fruiting body typical of Tomophagus colossus (syn. G. colossus); E) pseudostipitate (short stocky stipe (stalk)) form of $G$. sessile; F) Latterally pseudostipitate, reddish-orange fruiting body with a white margin typical of an actively growing $G$. tsugae fruiting body. Credits: A) through E) Andrew Loyd, UF/IFAS; F) Robert Blanchette, University of Minnesota, Department of Plant Pathology

Microscopically, spore size and shape can distinguish some species, but in most species the spores are quite similar. All Ganoderma species have bitunicate (double-walled) basidiospores that are pigmented, appearing golden-brown (Figure 4A). The inner wall is pigmented and extends through the hyaline (not pigmented) outer wall as small pillars, making the spores appear subtly echinulate (spiny) under the light microscope (Figure 4A). Some species have spores that appear "rough," while others have spores that appear "smooth." The distinction between "rough" and "smooth" spores can be subjective and is only a relative distinction among the species, resulting from differences in the thickness and abundance of pillars from the inner spore wall (Steyaert 1980) (Figure 4). Lastly, there are species of Ganoderma that produce chlamydospores in the fruiting body or in culture. Chlamydospores are thick-walled asexual spores that function as survival structures, which can persist in extreme temperatures and drying conditions. These structures are variable within the genus Ganoderma and can be hyaline to pigmented, round to obovate, and smooth or ornamented, depending on the species (Figure 4). A rudimentary key to the southeastern US laccate Ganoderma species is provided below.
A

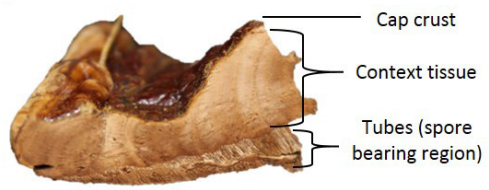

C

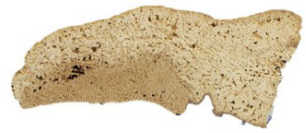

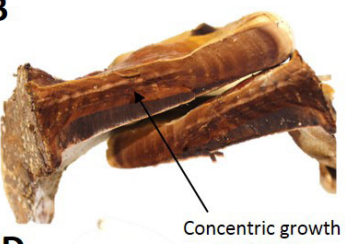

D
Concentric growth context tissue
Figure 3. Range of context tissue characters of the laccate Ganoderma spp. A) Cream-colored context tissue with concentric growth zones typical of G. sessile, illustrating the location of specific basidiocarp tissues; B) Dark brown colored context tissue with concentric growth zones (arrow) of G. tuberculosum; C) All white, homogenous context tissue of G. tsugae; D) Cream-colored context tissue with black, shiny resinous bands (arrow) typical of G. curtisii.

Credits: Andrew Loyd, UF/IFAS
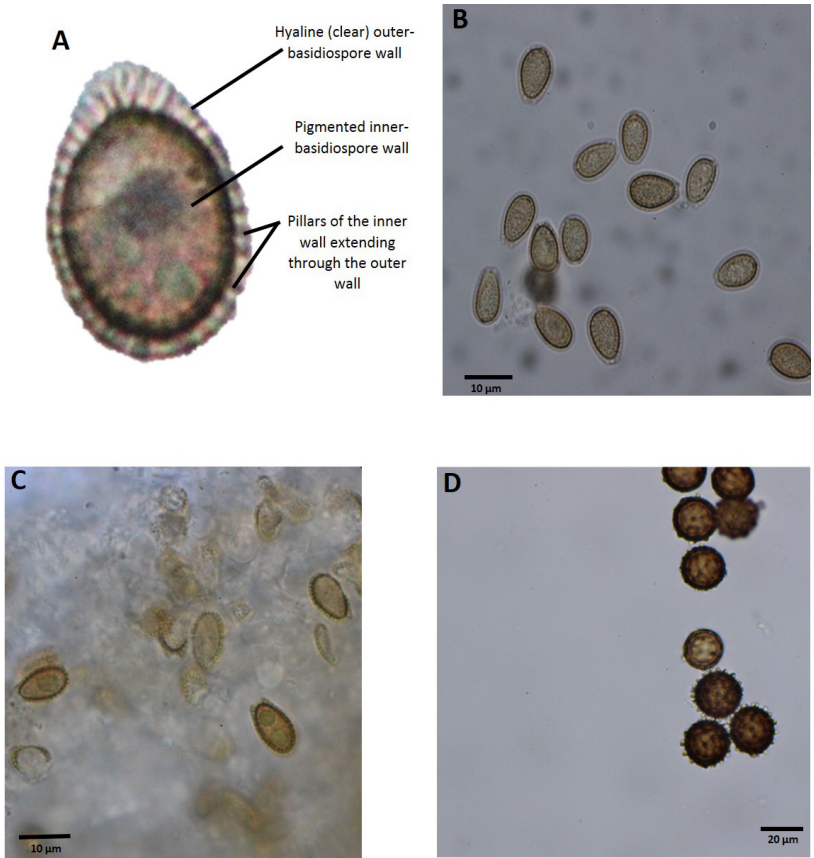

Figure 4. Basidiospore and chlamydospore morphology. A) Typical morphology of basidiospores of Ganoderma species, depicting the hyaline (non-pigmented) outer wall and pigmented inner wall that protrudes through the outer wall as small pillars; B) "Smooth" basidiospores of $G$. sessile, which appear smooth due to thin pillars of the inner spore wall; C) "Rough" basidiospores of G. curtisii, which appear rough due to thicker pillars of the inner spore wall; D) Pigmented, highly-ornamented, chlamydospores of T. colossus, which can be found consistently throughout the context tissue of the fruiting body.

Credits: Andrew Loyd, UF/IFAS 
A

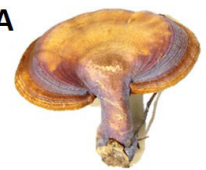

C

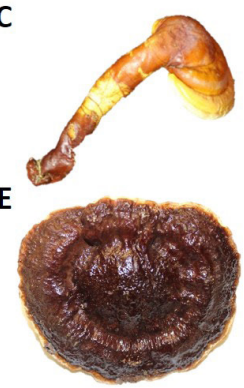

G

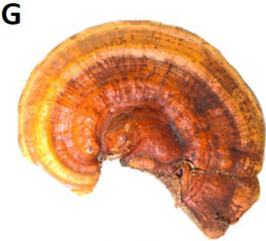

I

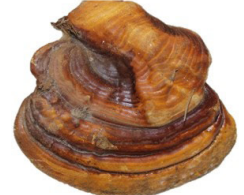

B

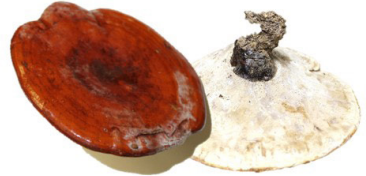

D

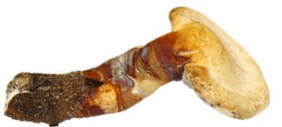

$\mathbf{F}$

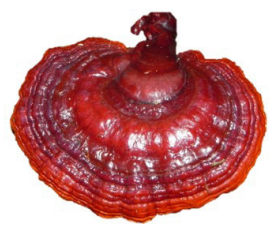

H

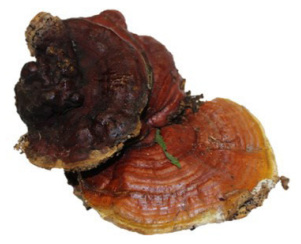

J

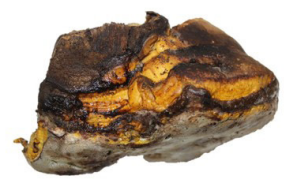

Figure 5. Representative fruiting bodies of Ganoderma species from the southeastern United States. Disclaimer: morphology of fruiting bodies can be highly variable within a species due to age, environment, and location. (A-J) These represent fruiting bodies of typical form from collections within the southeastern United States: A) G. curtisii, B) G. martinicense (top and bottom view), C) G. meredithiae, D) G. ravenelii, E) G. sessile, F) G. tsugae, G) G. tuberculosum, H) G. weberianum, I) G. zonatum, and J) Tomophagus colossus. Credits: A) through E) Andrew Loyd, U F/IFAS; F) Robert Blanchette, University of Minnesota, Department of Plant Pathology; G) through J) Andrew Loyd, UF/IFAS

\section{Basic Key to the Laccate Ganoderma spp. of the Southeastern United States}

Disclaimer: This key is rudimentary and is mostly based on macromorphology, geography, and host. This is not to be final and is based on species designations present in the literature at the date of this publication. The designations are subject to change as more investigations are made (Figure 5).

1. Typically stipitate fruiting body with a true stipe (commonly laterally produced). 2

1.Sessile fruiting body, or if a stipe is present, less than half the length of the cap diameter.. 4

2. Cream or buff context tissue with no black, shiny, resinous deposits G. ravenelii

2. Cream or buff context with black, shiny resinous deposits present. 3

3. Found predominately on hardwoods, especially oaks, growing from roots. G. curtisii

3. Found predominately on pines with a distribution in the Gulf South G. meredithiae

4. Fruiting body yellow, spongy (not woody), large basidio-

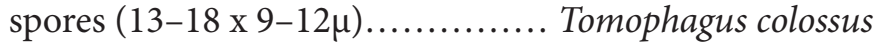

4. Not as above........................................................ 5

5. Context tissue dark brown............................................... 6

5. Context tissue white to cream to light brown............... 8

6. Found predominately on palms, slender basidiospores (length/width $\approx 2$ ). G. zonatum

6. Not as above 7

7. Mostly sessile, limited to South Florida, squatty basidiospores (length/width $\approx 1.3-1.5$ ).......... G. tuberculosum

7. Typically centrally pseudostipitate with resinous bands present in the context tissue. G. martinicense

8. Context tissue nearly pure white, in temperate locales, mainly on Tsuga spp. G. tsugae

8. Not as above 9

9. Pigmented chlamydospores in context tissue, limited to south Florida G. weberianum

9. No pigmented chlamydospores in context tissue, found in all states east of the Rockies. G. sessile

\section{Management}

With the exception of G. zonatum, a pathogenic species affecting virtually all palm species in the United States, Ganoderma species in the southeastern United States are mostly opportunistic pathogens that take advantage of stressed plants. Information on management for $G$. zonatum can be found in Ganoderma Butt Rot of Palms, http://edis.ifas.ufl.edu/pp100 (Elliott and Broschat 2000). Drought-stressed plants and plants growing under suboptimal conditions in urban settings appear to be more 
susceptible to decay by Ganoderma. Choosing the appropriate tree species that meets the expectations of maintenance inputs for a given landscape can be an effective management strategy to prevent and/or slow decay. For example, in low maintenance landscapes, such as median plantings along roadsides, utilizing relatively drought-tolerant plants can reduce the chances of pest problems such as decay fungi. Planting tree species that are chemically and physiologically tolerant to decay is another effective management tactic to avoid potential infections. Specific trees have different relative tolerance to fungal decay because of their chemical, morphological, and physiological characteristics (Scheffer and Cowling 1966; Scheffer and Morrell 1998). For example, black walnut and black locust are generally more tolerant to decay than cottonwoods and birches (Scheffer and Morrell 1998). Maintaining healthy trees by preventing wounding and providing proper fertilization, irrigation, mulching, and other plant health care tactics will improve the resiliency and resistance of trees to decay fungi.

When Ganoderma fruiting bodies are found in the landscape, a tree risk assessment, as outlined by the ISA Best Management Practice, should be performed to evaluate the level of hazard presented (Dunster et al. 2014). Fruiting bodies of Ganoderma can be found in trees with localized pockets of decay as well as trees that have extensive decay. Structure evaluations as basic as "sounding" the tree with a mallet or using a probe can estimate the extent of decay in a particular part of a tree. More advanced methods, such as using sonic and electrical resistance tomography, can also be used to quantify the area of decay within trees, relative to healthy wood. These types of approaches may help with management decisions, such as when to remove a tree because decay is extensive and the tree hazardous (Elliott et al. 2016).

\section{References}

Adaskaveg, J. and R. Gilbertson. 1988. "Ganoderma meredithae, a new species on pines in the southeastern United States." Mycotaxon 31: 251-257.

Adaskaveg, J. and R. Gilbertson. 1989. "Cultural studies of four North American species in the Ganoderma lucidum complex with comparisons to G. lucidum and G. tsugae." Mycological Research 92:182-191.

Cao, Y., S.-H. Wu, and Y.-C. Dai. 2012. "Species clarification of the prize medicinal Ganoderma mushroom "Lingzhi'”' Fungal Diversity 56:49-62.
Dunster, J. A., E.T. Smiley, N. Matheny, and S. Lilly. 2014. "Tree risk assessment manual." Arboricultural Journal: The International Journal of Urban Forestry 36:179-180.

Elliott, M. L. and T.K. Broschat. 2000. Ganoderma Butt Rot of Palms. PP54. Gainesville: Univeristy of Florida Institute of Food and Agricultural Sciences. http://edis.ifas.ufl.edu/ pp100

Elliott, M. and T. Broschat. 2001. "Observations and pathogenicity experiments on Ganoderma zonatum in Florida." Palms 45:62-73.

Elliott, M. L., T.K. Broschat, andL. Göcke. 2016. "Preliminary Evaluation of Electrical Resistance Tomography for Imaging Palm Trunks." Arboriculture \& Urban Forestry 42(2): 111-119.

Gilbertson, R. and L. Ryvarden. 1986. North American Polypores, vol. 1. Abortiporus to Lindteria, Fungiflora, Oslo. 443 pp., 1987. North American Polypores 2. Fungiflora, Oslo.

Hapuarachchi, K., T. Wen, C. Deng, J. Kang, and K. Hyde. 2015. "Mycosphere Essays 1: Taxonomic Confusion in the Ganoderma lucidum Species Complex." Mycosphere 6:542-559.

Hennicke, F., Z. Cheikh-Ali, T. Liebisch, J.G. Maciá-Vicente, H.B. Bode, and M. Piepenbring. 2016. "Distinguishing commercially grown Ganoderma lucidum from Ganoderma lingzhi from Europe and East Asia on the basis of morphology, molecular phylogeny, and triterpenic acid profiles." Phytochemistry 127:29-37.

Moncalvo, J.-M., H.-F. Wang, and R.-S. Hseu. 1995. "Gene phylogeny of the Ganoderma lucidum complex based on ribosomal DNA sequences. Comparison with traditional taxonomic characters." Mycological Research 99:1489-1499.

Scheffer, T. C. and E.B. Cowling. 1966. "Natural resistance of wood to microbial deterioration." Annual Review of Phytopathology 4:147-168.

Scheffer, T. C. and J.J. Morrell. 1998. Natural durability of wood: a worldwide checklist of species. Corvallis, Or.: College of Forestry, Forest Research Laboratory, Oregon State University.

Sinclair, W. A. and H.H. Lyon. 2005. Diseases of trees and shrubs. Comstock Publishing Associates. 
Steyaert, R. L. 1980. "Study of Some Ganoderma Species."

Bull. du Jardin Bot. Nat. de Belgique/Bull. van de Nat.

Plantentuin van Blegie 50:135-186.

Wang, X. C., R.J. Xi, Y. Li, D.M. Wang, and Y.J. Yao. 2012.

"The species identity of the widely cultivated Ganoderma,

'G. lucidum' (Ling-zhi), in China.' PLoS One 7:e40857.

Zhou, L.-W., Y. Cao, S.-H. Wu, J. Vlasák, D.-W. Li, M.-J. Li, and Y.-C. Dai. 2015. "Global diversity of the Ganoderma lucidum complex (Ganodermataceae, Polyporales) inferred from morphology and multilocus phylogeny." Phytochemistry 114:7-15. 